\title{
Dampak Sosial, Ekonomi dan Lingkungan Pertambangan Pasir di Desa Luragung Landeuh Kuningan, Jawa Barat
}

\author{
Wina Waniatri12*, Muslihudin ${ }^{3}$, Sri Lestari ${ }^{4}$ \\ 1Fakultas Kehutanan, Universitas Kuningan, Kuningan. \\ 2Program Studi Magister Ilmu Lingkungan, Pascasarjana, Universitas Jenderal Soedirman, Purwokerto; \\ ${ }^{3}$ Fakultas Ilmu Sosial dan Ilmu Politik, Universitas Jenderal Soedirman, Purwokerto. \\ ${ }^{4}$ Fakultas Biologi, Universitas Jenderal Soedirman, Purwokerto
}

\begin{abstract}
ABSTRAK
Permasalahan dan isu strategis daerah pada bidang energi dan sumber daya mineral yang mempengaruhi kerusakan lingkungan hidup berdasarkan pada Rancangan Primer RPJMD 2018-2028 Kabupaten Kuningan yaitu kegiatan penambangan pasir ilegal dan perubahan lahan. Salah satu lokasi pertambangan di Kabupaten Kuningan berada di Desa Luragung Landeuh. Penelitian ini dilakukan untuk mengetahui proses kegiatan pertambangan pasir; serta mengetahui dampak negatif pertambangan pasir terhadap kualitas lingkungan. Penelitian ini menggunakan metode analisis deskriptif kualitatif. Kesimpulan penelitian ini adalah proses kegiatan pertambangan pasir PT. Anggun Jaya Mandiri di Desa Lurangung Landeuh Kecamatan Luragung Kabupaten Kuningan terdiri dari tahap pra-kontruksi, kontruksi, operasi, produksi, dan rencana pasca tambang. Dampak negatif kegiatan pertambangan pasir terhadap lingkungan adalah kebisingan, debu yang bertebaran, kerusakan infrastruktur jalan; Dampak positif kegiatan pertambangan pasir PT.AJM memberikan peningkatan peluang kerja, memperbaiki fasilitas desa, serta meningkatkan kas Desa Luragung Landeuh. Pandemi Covid-19 pada awal tahun 2020 telah mempengaruhi dalam penyelesaian konflik antara masyarakat dan pihak perusahaan pertambangan.
\end{abstract}

Kata kunci: Kabupaten Kuningan, kualitas lingkungan, pertambangan pasir, dampak lingkungan

\begin{abstract}
Regional strategic problems and issues in the field of energy and mineral resources that affect environmental damage based on the Primary Draft RPJMD 2018-2028 Kuningan Regency, namely illegal sand mining activities and land changes. One of the mining locations in Kuningan Regency is in Luragung Landeuh Village. This research was conducted to determine the process of sand mining activities; as well as knowing the negative impact of sand mining on environmental quality. This study uses a qualitative descriptive analysis method. The conclusions of this study are: (1) The process of sand mining activities of PT. Anggun Jaya Mandiri in Lurangung Landeuh Village, Luragung District, Kuningan Regency consists of pre-construction, construction, operation, production, and post-mining planning stages. The negative impacts of sand mining activities on the environment are noise, scattered dust, damage to road infrastructure; (2) The positive impact of PT.AJM's sand mining activities provides increased job opportunities, improves village facilities, and increases the cash flow of Luragung Landeuh Village. The Covid-19 pandemic at the beginning of 2020 has affected the resolution of conflicts between the community and the mining company.
\end{abstract}

Keywords: Kuningan Regency, environmental quality, sand mining, environmental impact

Citation: Waniatri, W., Muslihudin., Lestari, S. (2022). Dampak Sosial, Ekonomi dan Lingkungan Pertambangan Pasir di Desa Luragung Landeuh Kuningan, Jawa Barat Jurnal Ilmu Lingkungan, 20(2), 279-290, doi:10.14710/jil.20.2.279-290

\section{Latar Belakang}

Kegiatan penambangan sebagian besar tidak memiliki izin usaha, Kondisi tersebut sebagian kecil telah ditangani secara hukum di pengadilan, tetapi banyak juga yang belum mengambil tindakan hukum secara tegas. Belum adanya penindakan secara hukum karena implementasi kebijakan pemerintah belum dilakukan secara optimal (Ismail, 2007). Pertambangan adalah sebagian atau seluruh tahapan kegiatan dalam rangka penelitian, pengelolaan dan pengusahaan mineral atau batubara yang meliputi penyelidikan umum, eksplorasi, studi kelayakan, konstruksi, penambangan, pengolahan dan pemurnian, pengangkutan dan penjualan, serta kegiatan pascatambang (UU Minerba No. 4 Tahun 2009).

Peran pemerintah di Indonesia baik pusat muapun daerah sebagai stakeholder dalam menangani permasalahan lingkungan dalam pelaksanaanya masih lemah. Pemerintah lebih terfokus pada upaya penaikan pendapatan asli daerah, serta tidak terlalu memperdulikan permasalahan lingkungan lainnya. Hal tersebut yang menyebabkan terjadinya konflik hampir di semua kawasan

\footnotetext{
*Penulis Korespondensi: wina.waniatri@mhs.unsoed.ac.id
} 
pertambangan. Pemerintah seharusnya dapat memandang fenomena konflik sosial yang akan muncul dan langsung melakukan aksi pencegahan (Zulkifli, 2014).

Pertambangan galian pasir (Galian C) di wilayah desa Luragung Landeuh direncanakan sejak tahun 2017. Pemerintahan Desa Luragung Landeuh tidak pernah libatkan masyarakat dalam musyawarah perencanaan kegiatan pertambangan. PT Anggun Jaya Mandiri mulai aktif beroperasi pada akhir tahun 2019. PT Anggun Jaya Mandiri tidak mempunyai dokumen Analisis Mengenai Dampak Lingkungan (AMDAL) sehingga dianggap sebagai penambang illegal. Usaha kegiatan pertambangan telah ditegaskan dalam Peraturan Menteri Lingkungan Hidup No. P38 Tahun 2019 pasal 3 ayat (1) yang berbunyi "Setiap rencana usaha dan atau/kegiatan yang berdampak penting terhadap lingkungan hidup wajib memiliki amdal". Penambangan pasir di Luragung Landeuh cacat hukum karena memiliki luas kurang lebih 35 Ha namun tidak memiliki AMDAL.

Berdasarkan observasi lapangan, lokasi pertambangan galian pasir di Desa Luragung Landeuh oleh PT Anggun Jaya Mandiri dekat dengan pemukiman warga. Jarak antara penambangan pasir ke perumahan Luragung adalah 429 m, ke SMKN 1 Luragung adalah $133 \mathrm{~m}$, ke Dusun Pahing adalah $175 \mathrm{~m}$, ke area pesawahan adalah $629 \mathrm{~m}$, ke Desa Dukuh Maja adalah 653 m, dan ke Dusun Wage adalah 204 m. Dari data tersebut dipastikan bahwa penambangan galian pasir sangat mengganggu kesehatan dan kualitas lingkungan setempat. Kerusakan lingkungan yang sangat mengkhawatirkan bukan merupakan masalah satusatunya yang terjadi akibat penambangan. Dampak aktivitas penambang menyebabkan adanya gesekan masyarakat dan berpotensi terjadinya konflik horizontal di masyarakat. Tujuan penelitian ini adalah untuk mengetahui proses kegiatan pertambangan pasir dan mengetahui dampak pertambangan pasir terhadap kualitas lingkungan di Desa Lurangung Landeuh Kecamatan luragung Kabupaten Kuningan.

\section{Metode Penelitian}

\subsection{Metode Penelitian}

Penelitian ini menggunakan metode analisis deskriptif kualitatif. Teknik pengumpulan data dilakukan dengan cara observasi, dokumentasi, dan wawancara yang dilakukan di Desa Luragung Landeuh.

\subsection{Lokasi Penelitian}

Penelitian dilakukan di Desa Luragung Landeuh, Kabupaten Kuningan Provinsi Jawa Barat, yang merupakan salah satu lokasi penambangan pasir yang terdapat di Provinsi Jawa Barat.

\subsection{Variabel Penelitian}

Variabel penelitian adalah segala sesuatu dalam bentuk apapun yang ditentukan oleh peneliti untuk dipelajari sehingga mendapatkan informasi yang diperlukan, kemudian dilakukan penarikan kesimpulan.

Variabel yang diamati dalam penelitian ini menyangkut 3 hal, diantaranya:

- Variabel biotik : jenis vegetasi dan produktivitas hasil pertanian.

- Variabel abiotik : kualitas air meliputi suhu, daya hantar listrik, residu terlarut; dan kualitas tanah meliputi sifat fisika kimia tanah.

- Variabel sosial dan ekonomi : aktivitas perekonomian, tingkat pendapatan, mata pencaharian, persepsi masyarakat terhadap pertambangan, kesehatan masyarakat, dan konflik sosial.

\subsection{Populasi dan Sampel}

Penentuan responden untuk data kualitatif pada penelitian ini menggunakan teknik Snowball Sampling. Teknik snowball sampling adalah cara yang dapat diandalkan untuk menemukan atau mengidentifikasi responden sebagai target penelitian, melalui keterkaitan dalam suatu jaringan. Sasaran penelitian ini adalah masyarakat pada 5 dusun (Dusun Pahing, Dusun Manis, Dusun Wage, Dusun Puhun, dan Dusun Babakan), pemerintah Desa dan Kabupaten, pihak penambang pasir, dan organisasi masyarakat Luragung.

\subsection{Analisis Data}

\subsubsection{Analisis Variabel Biotik}

\section{a) Analisis Vegetasi}

Metode yang digunakan pada penelitian ini metode PCQ (Point Centered Quarter) yang merupakan salah satu metode jarak (Distance Method). Metode ini tidak menggunakan petak contoh atau kuadran (plotless).

\section{b) Analisis Produktivitas Hasil Sawah}

Produktivitas lahan adalah potensi lahan dalam usahatani untuk menghasilkan pada tingkat produksi dan satuan luas tertentu seperti tingkat produksi yang dapat dicapai per hektar dalam satu musim tanam. Menurut Sinungan (2003), produktivitas adalah hasil per satuan dari suatu input (masukan). Pengukuran produktivitas input sebagai jumlah output per unit input. Berdasarkan teori tersebut maka produktivitas lahan dianalisa menggunakan rumus:

$$
\text { Produktivitas lahan padi sawah }=\frac{\text { Jumlah produksi panen }(\text { ton })}{\text { Luas lahan }(\mathrm{Ha})}
$$

\subsubsection{Analisis Variabel Abiotik}

a) Kualitas Air

Data kualitas air merupakan data sekunder yang diperoleh dari hasil pemantauan Dinas Lingkungan Hidup Kabupaten Kuningan pada bulan Januari 2021. 
b) Kualitas Tanah

Data kualitas tanah merupakan data sekunder yang diperoleh dari hasil penelitian sebelumnya yang telah dilakukan uji laboratorium pada tahun 2020 oleh mahasiswa Universitas Kuningan. Uji tanah adalah cara penentuan status unsur hara di dalam tanah dan sifat fisik tanah secara cepat dan akurat serta dapat diulang dengan analisis sifat fisik dan kimia tanah.

\section{c) Analisis Variabel Sosial dan Ekonomi}

Analisis variabel sosial dan ekonomi dilakukan dengan menggunakan analisis data deskrtiptif yang diperoleh melalui hasil wawancara dan dokumentasi. Analisis data deskriptif adalah suatu teknik analisa yang berfungsi untuk mendeskripsikan atau memberikan gambaran terhadap obyek yang diteliti (berupa data dari sampel atau populasi) apa adanya.

\section{Hasil dan Pembahasan}

\subsection{Gambaran Umum Lokasi Penelitian}

\subsubsection{Gambaran Umum Desa Luragung Landeuh}

Desa Luragung Landeuh merupakan salah satu dari 16 Desa yang terdapat di Kecamatan Luragung Kabupaten Kuningan Provinsi Jawa Barat. Jarak dari Ibukota Kabupaten Kuningan ke Desa Luragung Landeuh sekitar 18,8 km. Gambaran umum Desa Lurangung Landeuh disajikan pada Tabel 1.

\subsubsection{Gambaran Umum Lokasi Pertambangan}

Kegiatan penambangan pasir dalam penelitian ini berlokasi di Desa Luragung Landeuh, Kecamatan Luragung, Kabupaten Kuningan, Jawa Barat. Pemilik tambang berizin ini adalah $\mathrm{H}$. Yayat Sudayat dengan nama perusahaan yaitu PT. Anggun Jaya Mandiri (PT. AJM). Kepala Teknik Tambang (KTT) di PT. AJM ini bernama Deris Hariadi yang berasal dari lulusan pendidikan Teknik Pertambangan. Bentuk kawasan penggalian pasir dibuat sejajar dengan level sungai yang ada. Metode tambang terbuka (open pit mining) dengan teknik penambangan sistem quarry merupakan metode yang digunakan dalam kegiatan pertambangan tersebut. Gambar 1 merupakan lokasi galian pertambangan pasir PT. Anggun Jaya Mandiri.

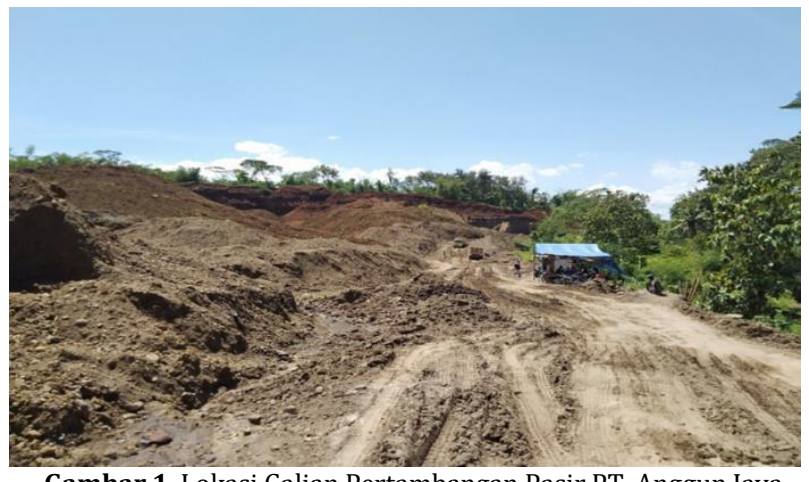

Gambar 1. Lokasi Galian Pertambangan Pasir PT. Anggun Jaya Mandiri
Tabel 1. Gambaran umum Desa Luragung Landeuh

\begin{tabular}{ll}
\hline \hline Kondisi & Data Desa Luragung Landeuh \\
\hline Luas Wilayah & 3223,633 Ha \\
Batas Wilayah & Sebelah Utara : Desa Dukuh maja \\
& Sebelah Timur : Desa Cikadu wetan \\
& Sebelah Selatan : Desa Luragung tonggoh \\
& Sebelah Barat : Desa Sindang suka dan Desa \\
& Sindang sari \\
Ketinggian & $700-900 \mathrm{mdpl}$ \\
Jumlah Dusun & 5 Dusun \\
Jumlah Rt & 33 \\
Jumlah Rw & 8 \\
\hline \hline Sumber : Data Desa Luragung Landeuh, Kabupaten Kuningan (2021)
\end{tabular}

\subsection{Kegiatan Pertambangan Pasir di Desa Lurangung Landeuh}

Isu-isu yang beredar di media masa bahwa PT.AJM berdiri dengan prosedur yang cacat setelah dikonfirmasi dengan pihak Dinas Lingkungan Hidup dinyatakan bahwa isu tersebut tidak benar. UKL-UPL sudah dimiliki oleh pihak perusahaan PT.AJM sejak tahun 2016 dan operasionalnya baru dilakukan November 2019.

Kegiatan penambangan pasir telah memiliki SIPD dari Bupati Kuningan dan atau izin pengoperasian alat berat dari Dinas Pertambangan dan Energi Provinsi Jawa Barat. Sebelum beroperasi, pertambangan pasir ini telah memiliki Izin Ekplorasi pada bulan Juni tahun 2016 dengan SK IUP Eksprorasi yaitu Nomor: 540/KEP.57/10.1.02.0/BPMPT/2016. IUP Eksplorasi diberikan setelah melakukan proses untuk tahapan kegiatan Penyelidikan Umum, Eksplorasi, dan Studi Kelayakan di wilayah pertambangan. Kegiatan pertambangan pasir PT. Anggun Jaya Mandiri selanjutnya memiliki Izin Usaha Pertambangan Operasi Produksi (IUP OP) yang telah dikeluarkan pada tahun 2017 dengan Nomor IUP OP : 540/21/10.1.06.0/DPMPTSP/2017 dengan luas wilayah yaitu $35 \mathrm{Ha}$.

\subsubsection{Tahapan Kegiatan Pertambangan Pasir PT.AJM}

Berdasarkan hasil wawancara dengan Kepala Teknik Tambang (KTT), Kegiatan pertambangan pasir di PT. Anggun Jaya Mandiri terdiri dari tahap prakontruksi, operasi, produksi, serta pasca tambang:

1) Tahap Pra-kontruksi

a. Pembebasan lahan

Pembebasan lahan adalah kegiatan membeli tanah kepada penduduk. PT. AJM melakukan pembebasan lahan dengan membeli tanah yang dimiliki oleh sekitar 700 kepala keluarga di Desa Luragung Landeuh. Total luas kawasan yang telah dibebaskan yaitu 35 Ha untuk kegiatan pertambangan, dan sisa luas $3 \mathrm{Ha}$ digunakan untuk pembuatan akses jalan angkut pasir.

Menurut hasil pengamatan oleh Dinas Lingkungan Hidup Kabupaten Kuningan pada bulan November 2020 Status kepemilikan lahan PT.AJM awalnya merupakan lahan sewa dari masyarakat lalu pada akhirnya masyarakat menjual lahannya kepada 
pihak perusahaan. Dalam proses penetapan lahan penambangan tersebut dijelaskan oleh Bapak Deris Hariadi, ST sebagai KTT perusahaan tambang bahwa pemiliki tambang telah membeli lahan terlebih dahulu kepada masyarakat desa Luragung Landeuh.

\section{b. Penerimaan tenaga kerja}

Proses penerimaan tenaga kerja dilakukan melalui proses seleksi pada para pelamar kerja sesuai kemampuan bekerja di lapangan. Jumlah penambang pasir di PT. AJM yaitu sekitar 200 orang yang terdiri dari 180 orang masyarakat lokal dan 20 orang masyarakat dari luar desa. Tingkat pendidikan para penambang pasir rata-rata hanya sampai jenjang SMP dan SMA sedangkan untuk tenaga kerja bagian kantor memiliki tingkat pendidikan hingga sarjana.

\section{2) Tahap Kontruksi}

Dalam tahap kontruksi ini kegiatan yang telah dilakukan PT. AJM adalah:

a. Perintisan (Pioneering)

Perintisan adalah kegiatan persiapan yang meliputi pembangunan jalan angkut dan penanganan sarana drainase air (saluran). Dalam pembangunan jalan, lebar dan kemiringan jalan sesuai dengan prosedur yang telah direncanakan sebelumnya sehingga hambatan dalam pengangkutan pasir dapat diatasi dan tingkat keselamatan pengguna jalan terjamin. Pembangunan jalan dilakukan dengan menggunakan bulldozer.

\section{b. Penebasan vegetasi (Clearing)}

Kegiatan atau pekerjaan membersihkan areal yang akan ditambang dari semak-semak, pohon-pohon kecil dan tanah serta bongkahan-bongkahan yang menghambat pekerjaan selanjutnya. Peralatan yang dipakai untuk membersihkan tanah tambang adalah tenaga kerja seperti gergaji, bulldozer, pick truck, dan penggaruk (ripper).

\section{c. Pengupasan tanah penutup (Stripping)}

Pengupasan dilakukan pada lapisan tanah tertutup bersamaan dengan pembukaan lahan dan menggunakan bulldozer. Pekerjaan diawali dari tempat yang lebih tinggi dan tanah yang tertutup didorong ke bawah menuju tempat yang lebih rendah sehingga alat dapat bekerja dengan bantuan gravitasi.

d. Pembangunan sarana dan prasarana persiapan pertambangan

Pembangunan sarana dan prasarana untuk mempersiapkan beroperasinya kegiatan pertambangan diantaranya :

- Membuat jalan masuk menuju lokasi penambangan

- Perataan dan pengerasan jalan menggunakan eksavator

- Pembangunan kantor, mushola, dan gudang solar

- Fasilitas pos steam dan pos jaga

- Adanya zona penyangga (buffer zone). e. Pengendalian dampak lingkungan

PT. AJM telah melakukan pembangunan untuk pencegahan dari kerusakan lingkungan. Misalnya ketika musim hujan, PT.AJM telah membuat kolam penampungan air untuk disaring terlebih dahulu agar pasir tidak ikut terbawa ke sungai. Selain itu, PT.AJM membuat jenjang pengaman yang telah disesuaikan dengan kondisi lapangan agar terhindar dari erosi dan longsor. Selanjutnya untuk bagian atas sebagian sudah mulai ditanami vegetasi akan tetapi belum bersifat permanen dengan luasan sekitar $600 \mathrm{~m}^{2}$.

Selanjutnya terdapat juga mobil yang berfungsi untuk melakukan penyiraman air di jalan untuk mengurangi debu yang berterbangan seperti pada Gambar 2. Penyiraman jalan dilakukan pada siang hari ketika kondisi jalan tanah yang kering dan gersang. Penanaman pohon di sekeliling lokasi penambangan juga penting dilakukan karena berfungsi untuk meredam kibisingan dan penahan debu seperti pada Gambar 3.

3) Tahap Operasi/Produksi

Kegiatan Operasi Pertambangan di PT. AJM dilakukan sekitar 9 hingga 10 jam setiap harinya yang dimulai dari pukul 06.00 - 15.00 WIB. Jam istirahat pada siang hari pada pukul 12.00 - 13.00 WIB yang digunakan para pekerja untuk beribadah dan makan siang. Kegiatan pertambangan pasir beroperasi setiap hari, akan tetapi jika cuaca kurang mendukung seperti ketika musim hujan yang deras akan membuat para pekerja tambang menghentikan aktifitasnya untuk menjaga keamanan pekerja dari hal-hal yang tidak diinginkan.

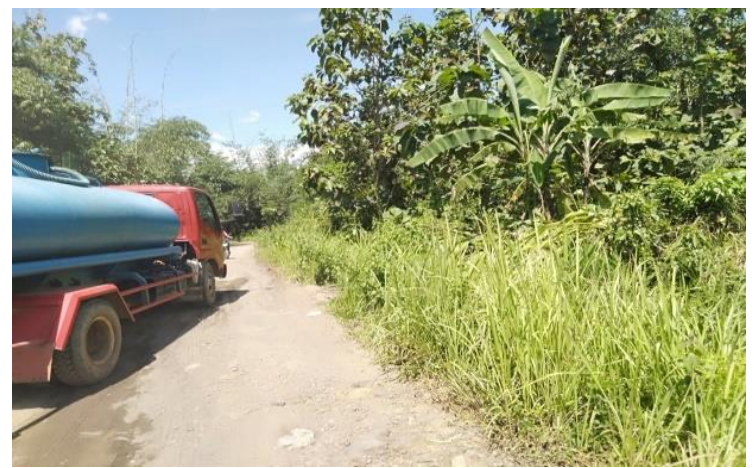

Gambar 2. Mobil Tangki Air yang berfungsi untuk Penyiraman Jalan

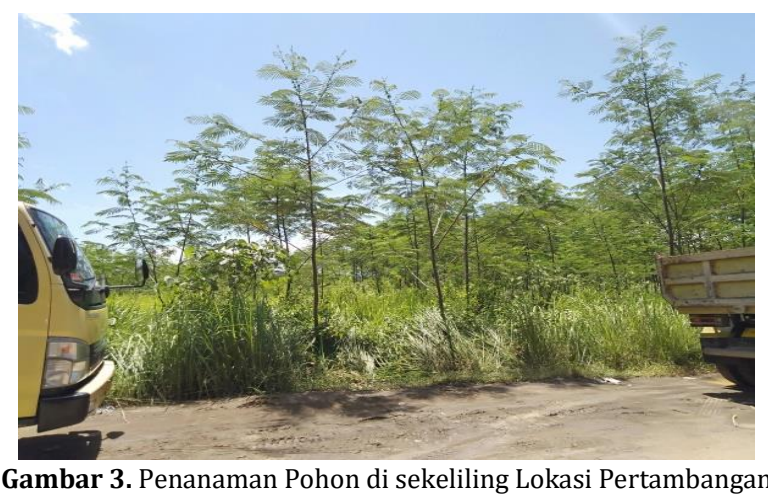

(C) 2022, Program Studi Ilmu Lingkungan Sekolah Pascasarjana UNDIP 
Pekerja pertambangan bekerja secara berkelompok dan setiap kelompok dikoordinasikan oleh seorang pengawas lapangan. Tugas pengawas antara lain mengontrol pekerja, mengatur kriteria dan jumlah pekerja, serta menjaga keselamatan kerja. Pada lokasi penambangan pasir di Desa Luragung Landeuh terdapat 15 orang pengawas dan sekitar 200 orang pekerja.

\section{a. Penggalian Pasir}

Kegiatan penggalian pasir menggunakan alat-alat diantaranya ekcavator, bulldozer, dan cangkul. Pasir yang telah dipisahkan dari bebatuan dan kerikil langsung dialihkan ke tempat pengumpulan pasir. Pemuatan pasir dilakukan untuk memindahkan hasil galian dari daerah tambang sampai ke tempat penyerahan dan pemasaran. Jenis kendaraan yang digunakan untuk pengangkutan pasir yaitu truk. Kendaraan pengangkut pasir ini dapat memuat sekitar 4,5 hingga 5 kubik/truk. Jumlah pasir yang ditambang oleh PT. AJM berkisar 100 kubik/hari.

\section{b. Kegiatan jual beli pasir}

Setiap truk yang datang akan mencari seorang pengawas yang telah diberi wewenang dan kuasa oleh pemilik tambang untuk bernegosiasi dengan pembeli pasir. Di pintu masuk terdapat pos penjaga yang mengawasi keluar masuknya truk pasir, tenaga kerja yang bertugas di pos jaga berjumlah sekitar 5 orang. Jumlah truk yang keluar masuk lokasi pertambangan tidak dibatasi. Truk-truk yang mencari pasir akan ramai berdatangan ketika musim kemarau disebabkan banyaknya kegiatan pembangunan yang membutuhkan pasir sebagai bahan baku, sedangkan ketika musim hujan walaupun kegiatan jual beli pasir masih dilaksanakan kan tetapi mengalami penurunan dalam pembeliannya.

PT.AJM memasarkan atau menjual hasil galiannya hanya di wilayah Kabupaten Kuningan dan Cirebon. Harga pasir yang dijual PT.AJM mengikuti harga standar di Kabupaten Kuningan yaitu Rp 365.000/truk.

\section{4) Tahap Pasca Tambang}

Lama waktu beroperasinya perusahaan tambang dipengaruhi oleh kebutuhan pasar. Kebutuhan pasar dalam kesediaan pasir untuk dijual setiap tahunnya berbeda. Pihak perusahaan menghitung perkiraan jumlah volume pasir yang dapat disediakan untuk kebutuhan pasar yang tidak menentu. Jika kebutuhan pasar semakin tinggi maka kesediaan bahan pasir semakin berkurang.

PT. AJM yang dimiliki oleh H. Yayat Sudayat telah membuat perencanaan mengenai reklamasi yang dikeluarkan pada bulan Februari tahun 2017. Lahan baru dapat direklamasi setelah $4-5$ tahun perusahaan telah beroperasi yang sebelumnya melakuakan pengajuan terlebih dahulu kepada pihak pemerintah provinsi. Tahap pasca tambang merupakan kegiatan yang telah direncanakan dengan sistematis dan berkelanjutan setelah berakhirnya sebagian atau seluruh kegiatan usaha pertambangan untuk memperbaiki lingkungan alam dan sosial sesuai dengan kondisi setempat di sekitar pertambangan. Salah satu kegiatan pasca tambang adalah reklamasi. Reklamasi merupakan kegiatan yang dilakukan pada semua tahapan usaha pertambangan untuk menata, memperbaiki, dan meningkatkan kualitas lingkungan dan ekosistem supaya berfungsi kembali sesuai fungsinya.

Menurut Suhartanto (2007), reklamasi lahan adalah suatu upaya pemanfaatan, perbaikan, dan peningkatan kesuburan lahan yang rusak secara alami maupun pengaruh manusia melalui penerapan teknologi maupun pemberdayaan manusia. Sedangkan menurut Young (2004), reklamasi berasal dari kata to reclaim yakni bermakna to bring back to proper state, artinya adalah membuat kondisi menjadi lebih baik, serta tidak mengandung implikasi pemulihan ke kondisi asal tetapi lebih mengutamakan fungsi dan azas pemanfaatan lahan. Tujuan akhir dari reklamasi lahan adalah memperbaiki bekas lahan tambang agar kondisinya aman, stabil, dan tidak mudah tererosi sehingga dapat dimanfaatkan kembali (Darwo, 2007).

\subsection{Dampak Pertambangan Pasir di Desa Luragung Landeuh}

Dampak negatif kegiatan pertambangan bisa dilihat dari adanya gangguan pada lingkungan fisik, biologis, sosial, budaya, ekonomi dan warisan nasional, serta gangguan terhadap ekologi dan pembangunan yang berkelanjutan (Makurwoto, 1995). Pengelolaan sumber daya pertambangan yang tidak berpedoman pada prinsip ekologi dapat menyebabkan kerusakan lingkungan yang tinggi. Jika melebihi daya dukung, daya tampung, dan ambang batas yang dapat dipulihkan, maka akan mengakibatkan kerusakan lingkungan yang permanen. Ancaman terhadap kerusakan lingkungan seperti perubahan bentang alam yang besar, perubahan morfologi dan kegunaan lahan, penimbunan tanah galian dan limbah pengolahan serta jaringan infrastrukturnya. (Zulkifli, 2014).

Meskipun kegiatan pertambangan dapat membantu peningkatan pada sektor ekonomi, akan tetapi dalam pelaksanaanya tidak boleh merusak ekosistem lingkungan. Sumber daya lain seperti hutan, tanah dan sumber air harus tetap terjaga pada saat operasi hingga pascatambang. Keseimbangan ekosistem lingkungan harus tetap terjaga, baik lingkungan alam, lingkungan buatan, maupun lingkungan sosial. Jika keseimbangan ekosistem lingkungan tidak dilindungi, karena lebih mengutamakan lingkungan buatan di atas lingkungan sosial dan alam, maka lingkungan akan terganggu dan rusak, menimbulkan konflik sosial, dan mengakibatkan terganggunya proses penambangan. Keseimbangan ekosistem lingkungan yang terjaga dapat membuat lingkungan sosial masyarakat tetap serasi, lingkungan buatan yaitu tambang tetap bisa melakukan usahanya, 
dan lingkungan alam dapat tetap lestari. (Zulkifli, 2014).

\subsubsection{Komponen Abiotik}

a) Kualitas Air

Permasalahan yang sering muncul dalam eksplorasi dan eksploitasi sumber daya mineral terjadi pada kualitas lingkungan diantaranya degradasi tanah, pencemaran udara, serta kerusakan hidrologi air. (Noor, 2006). Menurut Naiola, et al (1996) kegiatan pertambangan bisa mendorong terjadinya water table lebih dekat dengan permukaan tanah. Tanah dengan tingkat keasaman yang tinggi menyebabkan logam berat larut, dan pada ketika terjadi erosi dapat terbawa arus sehingga mencemari ekosistem perairan sekitar (Greene, 1998).

Tata guna lahan dengan ketersediaan air merupakan komponen yang tidak dapat dipisahkan. Penata gunaan lahan yang tepat pada lokasi tangkapan air dapat mempengaruhi kualitas air, pasokan air, serta pengaturan aliran kepada hilir. Air larian yang tinggi pada tanah permukaan mengakibatkan rendahnya air yang menyerap masuk ke tanah sehingga mengakibatkan air dalam tanah berkurang.

Kegiatan pertambangan pasir dalam operasionalnya berbeda dengan pertambangan batu bara yang menggunakan zat kimia untuk peledakan batu. Ibu Sri Mulyani sebagai Pengawas Lingkungan Hidup dari Dinas Lingkungan Hidup Kabupaten Kuningan menyatakan bahwa untuk perairan secara umum tidak ada masalah yang dapat merusak lingkungan, aliran tidak dinyatakan merusak lingkungan karena tidak ada zat kimia yang ikut mengalir sedangkan untuk masalah sedimentasi pihak PT. AJM telah membuat kolam penampungan air untuk dilakukan penyaringan terlebih dahulu.

PT.AJM telah membuat kolam penampungan air yang berfungsi sebagai upaya untuk mencegah kerusakan pada sungai seperti sedimentasi, mendangkalan sungai, dan menyempitan badan sungai. Pada bulan Januari 2021 telah dilakukan pemantauan kembali oleh Ibu Sri Mulyani sebagai Pengawas Lingkungan Hidup Kabupaten Kuningan. Berdasarkan hasil pemantauan di lapangan dan wawancara dengan Dinas Lingkungan Hidup, PT. AJM dalam kegiatan pertambangannya tidak menimbulkan kerusakan pada kualitas air. Dinas Lingkungan Hidup Kabupaten Kuningan telah melakukan penilaian baku mutu kualitas lingkungan di lokasi pertambangan milik PT. Anggun Jaya Mandiri.

Tabel 2. Hasil Analisis Kualitas Fisik Air Hasil Pengukuran

\begin{tabular}{cccccc} 
Parameter & Satuan & St 1 & St 2 & St 3 & St 4 \\
\hline Suhu & ${ }^{\circ} \mathrm{C}$ & 30,3 & 29,5 & 29,4 & 29,2 \\
TDS & $(\mathrm{mg} / \mathrm{L})$ & 105 & 130,7 & 111 & 122,4 \\
DHL & $\mu \mathrm{S} / \mathrm{cm}$ & 101,6 & 123,3 & 196,4 & 107,4 \\
\hline
\end{tabular}

Sumber : Dinas Lingkungan Hidup Kabupaten Kuningan, 2021
Hasil wawancara dengan Ibu Sri Mulyani, S.Si sebagai Pengawas Lingkungan Kabupaten Kuningan yang telah melakukan pemantauan secara langsung, menyatakan bahwa kerusakan kualitas air pada aliran sungai di Desa Luragung Landeuh bukan disebabkan oleh adanya perusahaan pertambangan, tetapi disebabkan limbah domestik dari masyarakat sekitar. Sampah domestik terlihat jelas terdapat pada bagian sungai. Kesadaran masyarakat mengenai pelestarian lingkungan belum sepenuhnya dimiliki oleh masyarakat Desa Luragung Landeuh.Hasil analisis kualitas fisik air di 4 stasiun (St) lokasi pengukuran terdapat pada Tabel 2.

Stasiun 1 adalah stasiun yang terletak di perbatasan Desa Luragung Landeuh sehingga pada stasiun 1 kami anggap sebagai hulu sungai yang melewati lokasi pertambangan pasir. Pada hasil pengukuran parameter kualitas fisik suhu, didapatkan bahwa suhu, TDS, dan DHL masih memenuhi baku mutu air yang ditetapkan dalam PP No. 20 tahun 1990, baik itu baku mutu suhu, TDS dan DHL yang ditetapkan untuk air golongan $\mathrm{A}, \mathrm{B}, \mathrm{C}$, maupun $\mathrm{D}$.

Berdasarkan pengukuran suhu, DHL, dan TDS, secara fisik air sungai pada hulu Desa Luragung Landeuh kondisinya masih bagus, karena secara fisik bisa digolongkan pada golongan A. Sesuai dengan standar baku mutu air minum SK Menkes RI No.907/MENKES/VII/2002 adalah $27^{\circ} \mathrm{C}$, sehingga berdasarkan standar baku mutu air minum, air di sungai sudah melebihi nilai ambang batas dan tidak bisa di minum langsung tanpa pengolahan.

TDS (Total Dissolved Solid) yang tinggi di dalam perairan menunjukkan tingkat kekeruhan yang tinggi. Semakin keruh perairan maka akan semakin tinggi nilai TDSnya. Kekeruhan sangat ditentukan oleh partikel-partikel terlarut dan lumpur. Semakin banyak partikel atau bahan orgaik terlarut maka kekeruhan akan semakin meningkat (Effendi, 2003). Pada lokasi stasiun 2 yaitu pada lokasi penambangan didapatkan nilai TDS yang paling tinggi di antara stasiun lainnya. Lumpur dan pasir halus yang masuk ke bandan sungai dan akan meningkatkan kekeruhan yang terindikasi dari nilai TDS yang paling tinggi dibanding stasiun lainnya. Nilai TDS dari stasiun 1 ke stasiun 4 mengalami kecenderungan kenaikan dan nilai TDS yang paling tinggi terdapat pada lokasi penambangan. Walaupun mengalami kenaikan nilai TDS, akan tetapi nilai TDS masih berada di bawah baku mutu air baik air golongan A, B,C maupun D.

Besarnya nilai daya hantar listrik (DHL) digunakan sebagai indikator tingkat kesuburan perairan. Tingginya daya hantar listrik menandakan banyaknya jenis bahan organik dan mineral yang masuk sebagai limbah ke perairan. Pada kondisi normal, perairan memiliki nilai DHL berkisar antara 20-1500 $\mu \mathrm{S} / \mathrm{cm}$ (Boyd, 1979). Pengukuran daya hantar listrik (DHL) di stasiun 1 sampai stasiun 4 berkisar antara $100-200 \mu \mathrm{S} / \mathrm{cm}$, dan nilai tertinggi di stasiun 3 yaitu $196.4 \mu \mathrm{S} / \mathrm{cm}$ dan terendah di lokasi stasiun 1. 
b) Kualitas Tanah

Pengambilan sampel tanah pada penelitian ini diambil dari penelitian sebelumnya yang dilakukan pada bulan November 2020 dari lahan penambangan pasir yang berada di Desa Luragung Landeuh Kabupaten Kuningan. Penambangan pasir ini meyebabkan bagian top soil atau bagian paling atas tanah telah hilang karena kegiatan penambangan pasir. Bagian top soil ini adalah bagian pada tanah yang memiliki tingkat kesuburan lebih baik karena banyak terdapat bahan-bahan organik dari serasah pohon yang jatuh yang dapat membuat mikro dan makro organisme pun ada di bagian ini. Kegiatan penambangan banyak dilakukan dengan cara pembukaan hutan, pengikisan lapisan-lapisan tanah, pengerukan ataupun penimbunan. Hal ini menyebabkan hilangnya lapisan tanah atas, pemadatan tanah, penurunan unsur hara, toksisitas unsur-unsur tertentu dan hilangnya biodiversitas mikroba adalah dampak negatif terdapat pada lahan bekas tambang (Kurbaniana, 2012). Tanah yang kehilangan top soil membuat tanah menjadi kurang memiliki nilai produktivitas untuk dilakukan penanaman karena dapat membuat tanaman tumbuh menjadi kurang optimal. Pada Tabel 3 disajikan analisis fisika kimia tanah pada lahan pertambangan pasir di Desa Luragung Landeuh.

Berdasarkan analisis tanah tambang pasir di desa Luragung Landeuh, diketahui bahwa proporsi pasir pada lahan ini sangat tinggi serta untuk kandungan unsur hara yang bermanfaat bagi pertumbuhan tanaman sangat rendah. Hasil analisis fisika kimia tanah menunjukan bahwa tekstur pada lahan ini adalah berpasir serta unsur hara yang terkandung untuk tingkat kesuburan tanah terdapat pada kriteria yang sangat rendah seperti bahan organik, P, K, dan KTK. Perubahan sifat kimia mengakibatkan penurunkan $\mathrm{pH}$, organik tanah, unsur hara, dan KTK tanah, sedangkan perubahan biologi tanah mengakibatkan penurunan populasi organisme tanah.

Tabel 3. Analisis Fisika Kimia Tanah pada Lahan Tambang Pasir Desa Luragung Landeuh

\begin{tabular}{lll}
\hline Sifat Fisika dan Kimia & Nilai & Kriteria \\
\hline Tekstur (\%) : & & \\
-Pasir & 85 & Pasir \\
-Debu & 11 & \\
-Liat & 4 & \\
pH $\mathrm{H}_{2} \mathrm{O}$ & 6,0 & Agak masam \\
$\mathrm{pH} \mathrm{KCl}$ & 4,8 & Netral \\
C-organik (\%) & 0,45 & Sangat rendah \\
N-total (\%) & 0,52 & Tinggi \\
C/N & 0,86 & Sangat rendah \\
P tersedia & 6,98 & Sangat rendah \\
K tersedia & 8,93 & Sangat rendah \\
KTK & 4,00 & Sangat rendah \\
Kation dapat ditukar : & & \\
-K & 0,99 & Tinggi \\
-Na & 2,04 & Sangat tinggi \\
-Ca & 2,01 & Rendah \\
-Mg & 0,34 & Sangat rendah \\
\hline Sumber : Data Sekunder, 2020 &
\end{tabular}

Tanah tambang menjadi tanah yang marjinal karena dipengaruhi oleh kegiatan penambangan yang menyebabkan hilangnya top soil yang membuat tanah menjadi miskin bahan organik (Wiryono, 2006).

\subsubsection{Komponen Biotik}

a) Jenis Vegetasi

Dampak terhadap kondisi biotik yang ditimbulkan akibat aktivitas penambangan yaitu pada flora (tumbuhan / vegetasi) dan fauna (hewan) yang ada disana. Terganggunya tersebut karena tumbuhan yang ada di atas lokasi/lahan penambangan harus ditebang terlebih dahulu agar pasir maupun batu dapat digali oleh pekerja tambang. Tentunya dengan penebangan tumbuhan akan juga berdampak pada fauna (hewan) yang hidup didalam vegetasi tersebut. Dampaknya tersebut sangat jelas sekali karena habitat dari hewan tersebut ditebang, sehingga terjadi ketidakseimbangan ekosistem. Jika hal tersebut terus terjadi, maka hewan maupun tumbuhan yang semestinya hidup di wilayah tersebut akan punah. Selain hilangnya flora dan fauna yang ada di atas lokasi/lahan penambangan. Pengaruh terhadap vegetasi juga mempengaruhi iklim dalam skala lokal. Secara hidrologis, lahan tambang tidak mampu lagi mempertahankan fungsinya sebagai pengatur tata air. Hal ini karena terganggunya kemampuan lahan untuk menahan, menyerap, dan menyimpan air, karena tidak ada vegetasi atau tanaman penutup lahan (Sitorus, 2003).

Soemarwoto (1997) juga menjelaskan jika ekologi merupakan salah satu komponen dalam sistem pengelolaan lingkungan hidup yang harus ditinjau bersama dengan komponen lain untuk mendapatkan keputusan dan hasil yang seimbang antara elemen makhluk hidup dan lingkungan itu sendiri. Sehingga aspek ekologi merupakan salah satu aspek yang harus secara krusial diperhatikan, terlebih dalam kaitannya dengan konteks pemanfaatan sumber daya alam. Keraf (2010) juga secara tidak langsung menyatakan dalam berbagai permasalahan ekologi hingga ancaman krisis yang terjadi pada dewasa ini, tidaklah hanya disebabkan oleh faktor alam, namun juga faktor internal dari manusia sebagai pihak yang terus menerus berinteraksi dengan lingkungannya.

Hasil pengamatan vegetasi pada jalur pengangkutan dan di sekeliling lokasi pertambangan masih ditemukan beberapa jenis pohon dan tumbuhan. Jenis vegetasi di sekitar lokasi pertambangan disajikan pada Tabel 4. Saat ini PT. AJM hanya baru melakukan kegiatan penanaman seluas $600 \mathrm{~m} 2$ dibagian atas walaupun belum optimal. Pohon yang ditanam berasal dari jenis fast growing seperti akasia (Acasia mangium) dan sengon (Albizia chinensis). Penanaman pohon juga berfungsi untuk mengurangi kebisingan dan penahan debu dari kegiatan pertambangan. Kepala Teknik Tambang PT. AJM pun memberikan kesempatan kepada para buruh untuk melakukan penanaman di 
areal yang tidak dilakukan penambangan seperti pada (Gambar 4), dimana sebagian buruh melakukan penanaman singkong untuk kebutuhan pribadi mereka. Pemanfaatan lahan ini dapat memberikan dampak positif secara sosial dari pihak perusahaan dan para buruh sehingga terjalin dengan baik.

\section{b) Produktivitas lahan.}

Desa Luragung Landeuh memiliki organisasi kelompok tani yang berjumlah 4 kelompok. Kelompok tani ini diantaranya Kelompok Tani Babakan, Kelompok Tani Gudang Tonjong, Kelompok Tani Bakom, dan Kelompok Tani Cimega. Tujuan terbentuknya kelompok tani adalah untuk menciptakan tata cara pemanfaatan sumber daya pertanian, sebagai alat pengembangan atau media, serta menciptakan kesadaran dari anggota petani agar dapat melaksankan amanat dari kelompok.

Hasil wawancara dari para petani pada 4 kelompok tani menyatakan bahwa PT. AJM yang telah beroperasi selama dua tahun tidak mempengaruhi produktivitas hasil sawah di Desa Luragung Landeuh. Menurut kelompok tani, adanya perusahaan pertambangan pasir tidak memberikan kerugian terhadap hasil pertanian dikarenakan aliran sungai utama yang bernama sungai Cisanggarung sebagai sumber utama kebutuhan air untuk kegiatan pertanian tidak melewati Perusahaan Tambang. Perusahaan tambang hanya dilewati oleh anak sungai, dimana anak sungai tersebut tidak berdekatan dengan kawasan pesawahan. Jarak lahan pertanian dengan penambangan pasir dengan pesawahan adalah $629 \mathrm{~m}$.

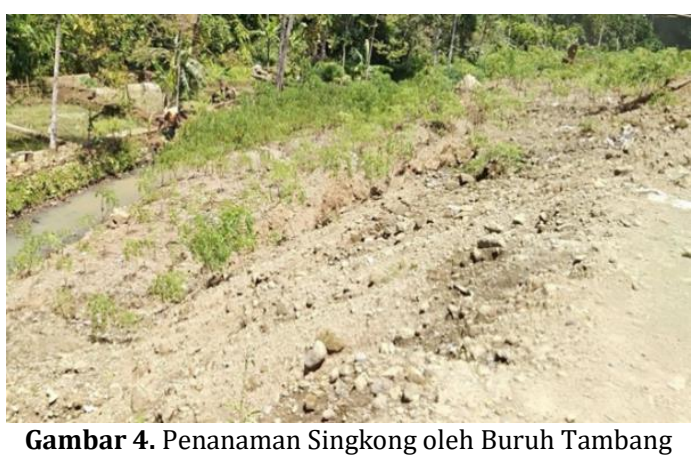

Tabel 4. Jenis Vegetasi yang berada di sekitar lokasi Pertambangan

\begin{tabular}{|c|c|c|}
\hline No & Nama & Nama llmiah \\
\hline 1. & Kapuk & Ceiba pentandra \\
\hline 2. & Mahoni & Swietenia mahagoni \\
\hline 3. & Petai & Parkia speciosa \\
\hline 4. & Jati & Tectona grandis \\
\hline 5. & Jati Putih & Gmelia arborea \\
\hline 6. & Mangga & Mangifera indica \\
\hline 7. & Akasia & Acasia mangium \\
\hline 8. & Sengon & Albizia chinensis \\
\hline 9. & Bambu & Bambusa Sp \\
\hline 10. & Kelapa & Cocos nucifera \\
\hline 11. & Pisang & Musa paradisiaca \\
\hline 12. & Singkong & Manihot esculenta \\
\hline 13. & Рepaya & Carica papaya \\
\hline 14. & Alang-alang & Imperata cylindrical \\
\hline
\end{tabular}

\subsubsection{Komponen Ekonomi}

Kegiatan industri pertambangan memiliki dampak positif dan negatif. Dampak positif kegiatan pertambangan adalah meningkatkan pendapatan asli daerah, membuka keterisolasian daerah, menyumbang devisa, menciptakan lapangan pekerjaan, pengadaan barang dan jasa, kegiatan produksi terkait, serta penyediaan sarana dan prasarana untuk peningkatan ekonomi lainnya (Mangkusubroto, 1995).

Dampak negatif berdasarkan data kondisi jalan yang ada di Desa Luragung Landeuh, terlihat bahwa masih banyak terdapat jalan yang rusak hingga rusak berat. Kondisi di Dusun Pahing terlihat sangat nyata, hal ini terjadi akibat dilalui oleh alat transportasi yang berat perusahaan pertambangan. Waktu yang diperlukan oleh pejalan kaki dan pengguna transportasi menjadi lebih lama disebabkan sementara waktu harus terhenti sejenak ketika truk angkutan pasir melintas yang membuat debu berterbangan. Waktu tempuh yang lama menyebabkan bahan bakar yang digunakan menjadi lebih banyak. Kondisi rusaknya jalan di Desa Luragung Landeuh dapat dilihat pada Gambar 5.

\section{a) Aktivitas Perekonomian}

Sarana perekonomian dapat dilihat dari banyaknya pertokoan maupun pasar yang terdapat di desa Luragung Landeuh. Pasar merupakan salah satu sarana perekonomian sebagai tempat transaksi perdagangan. Keberadaan pasar di Desa Luragung Landeh yang hanya terdapat 1 pasar membuat hampir dari setiap dusun berkunjung pasar ini untuk memenuhi kebutuhan rumah tangga. Keberadaan warung/kedai serta toko juga menjadi sarana dalam rantai pemasaran untuk mendistribusikan produksi kepada konsumen.

Pusat Perbelanjaan di Desa Luragung Landeuh selain pasar, diantaranya Toserba Fajar, Toserba Surya, Swalayan Sukanta Luragung, Indomaret, dan toko-toko sembako milik warga sekitarnya. Keberadaan warung makan pun sangat banyak, khususnya warung makan nasi kasreng yang merupakan ciri khas makanan dari wilayah Luragung.

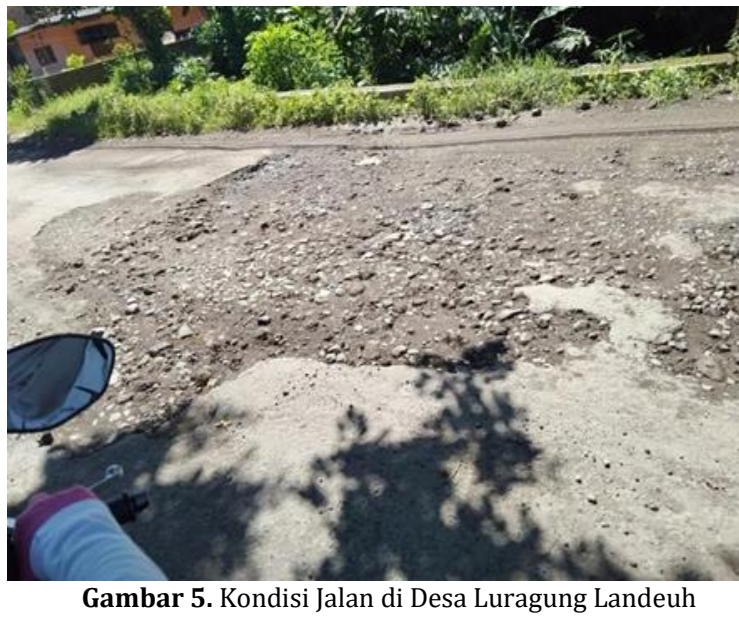

(C) 2022, Program Studi Ilmu Lingkungan Sekolah Pascasarjana UNDIP 
Jumlah unit Koperasi yang berada di Desa Luragung Landeuh hanya ada 1 koperasi. Koperasi simpan pinjam tersebut bernama KSP Bina Raharja Sindang Angung yang terletak di Dusun Pahing.

\section{b) Mata Pencaharian}

Mata pencaharian penduduk di Desa Luragung Landeuh umumnya berada di sektor pertanian, tranportasi P.O BUS, perdagangan, pertambangan, dan lain-lain. Mata pencaharian masyarakat sebelum terdapat kegiatan tambang pasir sebagian besar sebagai supir dan jasa cuci bus. Kegiatan pertambangan pasir PT. AJM memberikan dampak positif bagi masyarakat di Desa Luragung Landeuh. PT. AJM memberikan peluang pekerjaan pada masyarakat sekitar untuk menjadi penambang pasir. Jumlah penambang pasir yang berasal dari Desa Luragung landeuh mencapai 180 orang. Masyarakat yang awalnya mau bekerja di PT. AJM didominasi oleh orang-orang yang sebelumnya hanya berpenghasilan dari buruh pasar. Pihak perusahaan pun melakukan suatu seleksi, tidak semena-mena dalam merekrut pekerja. Tahap seleksi dilihat dari hasil berkas lamaran untuk menyesuaikan posisi yang dibutuhkan dan selanjutnya melalui tahap wawancara.

Hasil wawancara dengan beberapa buruh tambang, menyatakan bahwa dengan menjadi buruh atau tenaga kerja dipenambangan pasir lebih memberikan keuntungan dari pada buruh pasar dan buruh cuci bus serta menjadi penghasilan baru bagi para supir bus sebelumnya. Faktor yang menyebabkan masyarakat banyak yang memilih untuk bekerja di perusahaan tambang pasir salah satunya adalah karena faktor terjadinya pandemi Covid-19. Masyarakat Desa Luragung Landeuh yang dulu mengandalkan pendapatan dari sekor P.O Bus dan buruh pasar terjadi pengurangan pendapatan secara signifikan sehingga selain dari sektor pertanian sebagian dari masyarakat berusaha untuk bekerja menjadi tenaga kerja di penambangan pasir.

Desa Luragung Ladeuh dikenal dengan banyaknya pengusaha kendaraan P.O bus. Terjadinya pandemi Covid-19 pada awal tahun 2020 menyebabkan hampir bangkrutnya pengusaha P.O Bus Luragung. Hal tersebut menyebabkan para sopir dan para tukang cuci bus kehilangan pekerjaan sehingga penghasilan menurun. Para sopir bus yang kehilangan pekerjaannya pun akhirnya memilih untuk menjadi penambang pasir di PT. AJM. Posisi pekerjaan di perusahaan tambang pasir yang didapatkan memang bukan menjadi pegawai kantor yang memiliki jabatan, namun lebih pada pekerja teknis seperti buruh, supir dan bagian keamanan. Hal ini menunjukkan bahwa aktivitas pertambangan memberikan kontribusi terhadap pendapatan masyarakat di sekitar kawasan pertambangan, sehingga dengan terjadinya pandemi covid-19 masyarakat tidak kehilangan mata pencahariannya. c) Tingkat pendapatan,

Dampak ekonomi dari kegiatan pembangunan di sektor pertambangan adalah meningkatkan perekonomian masyarakat setempat, mengembangkan usaha mikro, mengembangkan kualitas sumber daya manusia, dan meningkatkan derajat kesehatan masyarakat setempat. (Salim, 2005). Pendapatan masyarakat sebelum aktivitas tambang dilakukan relatif lebih rendah dibandingkan pada saat pertambangan pasir mulai beroperasi. Hal tersebut menunjukkan bahwa aktivitas pertambangan memberikan kontribusi terhadap pendapatan masyarakat di sekitar kawasan pertambangan. Pendapatan dari kegiatan pertambangan pasir di desa Luragung Landeuh memiliki jumlah yang besar. Pendapatan terdiri dari 2 jenis yaitu pendapatan untuk kas desa dan pendapatan untuk penambang.

Pendapatan untuk penambang diantaranya adalah pemilik pasir, pengawas, dan pekerja/buruh tambang. Harga dari penjualan pasir yaitu $\mathrm{Rp}$ $365.000 /$ truk. Untuk setiap truk biasanya dapat mengangkut sekitar 4 kubik/ truk. Harga jual tanah setiap 1 truk setengahnya untuk pemilik pasir, selanjutnya di bagi untuk pengawas dan buruh tambang sekitar 4 orang yang mengumpulkan dan mengangkut pasir. Rata-rata pendapatan pekerja/buruh tambang yaitu Rp. 100.000 - Rp. 200.000 / harinya. Sebelum menjadi pekerja tambang sebagian besar masyrakat adalah sebagai buruh pasar dan pencuci bus dengan pendapatan Rp. 40.000 /hari sehingga adanya kegiatan pertambangan pasir dapat meningkatkan pendapatan dan kesejahteraan masyrakat Desa Luragung Landeuh.

Hasil wawancara yang dilakukan kepada Bapak Ruspandi, ST sebagai Kepala Desa Luragung Landeuh, menyatakan bahwa dari operasional penambangan pasir tersebut ada dana yang masuk untuk proses pembangunan desa. Dana yang diperoleh dari perusahaan tambang untuk pembangunan desa diantaranya telah dibangun fasilitas Posyandu untuk meningkatkan kesehatan masyarakat sekitar dan lapangan bola voli sebagai sarana olahraga dan hiburan bagi masyarakat Desa Luragung Landeuh. Pendapatan untuk Desa Luragung Landeuh berdasarkan peraturan desa yang berlaku, untuk setiap truk yang keluar mengangkut pasir harus membayar dengan jumlah Rp 5.000/truk sebagai retribusi jalan. Sopir truk membayar melalui pemuda karang taruna ketika melewati jalan masuk yang dapat dijadikan sebagai kas desa. Kas desa ini menurut kepala Desa Luragung Landeuh salah satunya telah dipergunakan untuk pembuatan lapangan volly yang dimanfaatkan oleh masyarakat sekitar untuk berolah raga.

\subsubsection{Komponen Sosial}

a) Kesehatan masyarakat,

Kondisi kesehatan masyarakat berdasarkan pada hasil wawancara di Puskesmas dan 5 dusun yang 
berada di Desa Luragung Landeuh tidak ditemukan adanya keluhan yang berasal dari kegiatan perusahaan tambang. Gangguan yang dirasakan oleh masyarakat sekitar hanya berupa kebisingan akibat transportasi yang sering lalu lalang.

Kesehatan lebih berdampak kepada para pekerja yang tidak memakai pelindung hidung dan mata ketika bekerja sehingga ketika debu yang berterbangan maupun jatuhnya tanah dari bagian atas menyebabkan mata menjadi sakit dan kotor serta debu yang terhirup menimbulkan gangguan pernafasan walau tidak terlalu parah.

\section{b) Persepsi dan konflik masyarakat}

Persepsi memiliki makna sebagai suatu proses kognitif yang dialami dan dimiliki oleh setiap orang dalam kaitannya dengan memahami informasi tentang lingkungannya, baik lewat penglihatan, pendengaran, penghayatan, perasaan, dan penciuman (Thoha, 2004). Berdasarkan definisi tersebut, persepsi memiliki sudut pandang subjektif yang tentunya akan dapat berbeda pada setiap manusia, karena proses kognitif, penafsiran serta pemaknaan terhadap subjek atau objek tertentunya akan memiliki bentuk atau intensitas yang berbeda. Banyak faktor yang pada dasarnya mempengaruhi persepsi dari individu itu sendiri, baik yang berasal dari faktor internal maupun eksternal, diantaranya seperti kondisi lingkungan, jenis pekerjaan, status sosial, karakteristik sosial dan ekonomi (Erwiantono, 2004).

Dinamika kehidupan masyarakat memliki potensi terjadinya konflik. Keberadaan sumber daya strategis, contohnya bahan tambang, mempunyai potensi untuk diperebutkan pihak perusahaan dan masyarakat sekitar. Persaingan untuk mengakses sumber daya, alat produksi dan peluang ekonomi adalah faktor mendasar dalam mendorong terjainya konflik.

Menurut level permasalahannya, konflik yang terjadi di Desa Luragung Landeuh dengan perusahaan tambang pasir merupakan konflik horizontal. Awal operasi kegiatan pertambangan pasir PT. AJM menimbulkan konflik sosial pada awal tahun 2019. Masyarakat terbagi menjadi dua golongan yaitu pro dan kontra terhadap operasi kegiatan pertambangan pasir. Berdasarkan hasil wawancara dapat diketahui bahwa konflik sosial terjadi disebebkan kurang baiknya hubungan antara perusahaan, perangkat desa, dan masyarakat sekitar. Penyebab konflik yang terjadi jika mengacu pada pemetaan konflik termasuk kedalam kriteria konflik hubungan antar manusia. Konflik hubungan antar manusia dapat disebabkan oleh kuatnya emosi negatif, persepsi dan komunikasi yang salah, atau berulangnya perilaku negatif (Fuad dan Maskanah, 2000).

Hasil wawancara dengan KTT PT. AJM yaitu bapak Deris Hariadi, S.T, menyatakan bahwa konflik sosial terjadi akibat masyarakat yang awam dan tidak memahami prosedur yang dilakukan perusahaan PT. AJM sudah dapat menjamin terhadap kesejahteraan masyarakat dan kualitas lingkungan sekitar. Menurut
Kepala Desa Luragung Landeuh, masyarakat yang kontra dan memanas terhadap kegiatan operasi pertambangan untuk memperjuangkan hak masyarakat yang tidak diikut sertakan dalam tahap awal perencanaan pembukaan lahan untuk pertambangan. Menurut bapak Deris sebagai KTT PT. AJM, masyarakat yang kontra bukan meruapakan bagian masyarakat yang peduli akan lingkungan. Bapak Deris menyatakan bahwa semua yang dilakukan telah sesuai dengan prosedur yang seharusnya untuk menghindari kerusakan kelestarian lingkungan.

Awalnya pemerintah mengetahui adanya konflik sosial yang terjadi disebabkan oleh adanya pengaduan dari pihak yang kontra dengan berdirinya perusahaan tambang. Masyarakat yang kontra terhadap berdirinya kegiatan pertambangan didominasi oleh masyarakat yang belum mengerti mengenai teknis prosedur perusahaan tambang dan dianggap sangat merugikan keberadaanya. Saat pihak kontra mengadu pada pemerintah, pemerintah belum mengetahui apakah pihak tersebut memiliki tempat tinggal yang berdekatan dengan lokasi pertambangan atau tidak. Pihak pengadu bisa saja berasal dari luar wilayah desa Luragung Landeuh maupun berasal dari pihak yang merasa tersaingi usahanya akibat berdirinya usaha pertambangan di wilayah tersebut. Fakta di lapangan ditemukan pula bahwa di sekitar Kecamatan Luragung terdapat juga banyak usaha pertambangan.

Selama ini konflik yang muncul di wilayah pertambangan merupakan adanya ketidakadilan ekonomi dan akses terhadap sumber daya yang rasakan oleh masyarakat. Wilayah eksplorasi dianggap masyarakan sebagai kampung halaman atau wilayah adat mereka, sedangkan perusahaan memandang kewenangan yang diperolehnya melalui hak izin pertambangan dan berhak untuk menggali bahan tambang sebanyak-banyaknya untuk kepentingannya sendiri. Kepentingan asimetris ini berpotensi terjadinya konflik mempunyai dampak merugikan bagi seluruh pihak. Konflik menunjukkan konfrontasi persepsi dan strategi stakeholder. Konflik berkaitan dengan situasi dimana ada dua stakeholder atau lebih yang ingin melakukan perubahan terhadap suatu faktor dengan arah yang bertentangan (Bots, 2008).

Kepala Desa Luragung Landeuh saat ini merupakan kepala desa yang baru mendapat jabatan pada akhir tahun 2020. Jabatan baru ini disebabkan kepala desa sebelumnya yang memiliki banyak kasus sehingga dilakukan pencopotan jabatan. Menurut Kepala Desa yang baru, konflik antara kepala desa sebelumnya dengan masyarakat adalah akibat kurangnya tranparansi antara masyarakat dan perangkat desa. Perangkat desa sebelumnya kurang melakukan sosilalisasi kepada masyarakat tentang perencanaan pembukaan kawasan pertambangan. Pickering (2000) mengemukaan dampak negatif konflik yaitu menyebabkan timbulnya keraguan atau ketidak inginan antar kelompok terhadap pihak perusahaan. Tipe konflik di permukaan adalah konflik yang mempunyai kedangkalan akar atau tidak berakar 
dan muncul disebabkan kesalahpahaman tentang sasaran yang dituju.

Saat ini, konflik tersebut telah mereda disebabkan oleh banyaknya masyarakat yang kehilangan pekerjaan akibat pandemi Covid-19. Pandemi Covid-19 yang terjadi pada awal tahun 2020 membuat banyaknya masyarakat Desa Luragung Landeuh kehilangan pekerjaan sebelumnya. Masyarakat yang kehilangan pekerjaannya akhirnya memutuskan untuk bekerja di tambang pasir PT. AJM. Banyaknya masyarakat yang menjadi tenaga kerja di PT. AJM sekaligus menurunkan ketegangan konflik karena pihak masyarakat dan pengusaha merasa saling menguntukan satu sama lain.

\section{Kesimpulan}

Kesimpulan dari penelitian ini adalah Proses kegiatan pertambangan pasir PT. Anggun Jaya Mandiri di Desa Lurangung Landeuh Kecamatan Luragung Kabupaten Kuningan terdiri dari tahap prakontruksi, kontruksi, operasi, produksi, dan rencana pasca tambang. Tahap pra-kontruksi meliputi pembebasan lahan dan penerimaan tenaga kerja; Tahap operasi meliputi perintisan (pioneering), penebasan vegetasi (clearing), pengupasan tanah penutup (stripping), pembangunan sarana dan prasarana persiapan pertambangan, serta pengendalian dampak lingkungan; Tahap kontruksi meliputi penggalian pasir dan kegiatan jual beli pasir; Rencana pasca tambang adalah reklamasi.

Dampak negatif kegiatan pertambangan pasir terhadap lingkungan adalah kebisingan, debu yang bertebaran, kerusakan infrastruktur jalan. Dampak positif kegiatan pertambangan pasir PT.AJM memberikan peningkatan peluang kerja, memperbaiki fasilitas desa, serta meningkatkan kas Desa Luragung Landeuh.

Dalam penelitian ini juga diperoleh fakta bahwa terjadinya pandemi Covid-19 pada awal tahun 2020 mempengaruhi dalam penyelesaian konflik antara masyarakat dan pihak perusahaan pertambangan.

\section{Saran}

Kelestarian lingkungan dan infrastruktur perlu ditingkatkan untuk kenyamanan masyarakat, kelestarian flora dan fauna, dan ekosistem lingkungan. Kegiatan dalam upaya menjaga kelestarian lingkungan, dapat dilakukan dengan:

a. Penggunaan energi ramah lingkungan misalnya penggunaan energi matahari pada lampu, biodiesel untuk angkutan dan sebagainya.

b. Penanaman pohon tidak hanya dilakukan pada saat pasca tambang namun juga dilakukan pada tahap operasi produk

c. Mengelola dengan baik limbah B3 (seperti kaleng bekas oli). d. Penanaman dilakukan disekitar jalur transportasi supaya bisa mengurangi polusi suara dan udara.

\section{DAFTAR PUSTAKA}

Bots, P.W.G. 2008. Analyzing actor networks while assuming "frame rationality." Cambridge.

Boyd. C.E. 1979. Water Quality in Warmwater Fish. Aurburn University Agricultural Experimental Station. Albama.

Darwo. 2007. Strategi Peningkatan Program Gerhan (Studi Kasus Gerhan di Sekitar Daerah Tangkapan Air Danau Toba). Prosiding Ekspose Hasil-hasil Penelitian: Konservasi dan Rehabilitasi Sumber Daya Hutan. Pusat Litbang Hutan dan Konservasi Alam.

Effendi, H. 2003. Telaah Kualitas Air Bagi Pengelolaan Sumberdaya dan Lingkungan Perairan. Penerbit Kanisius. Yogyakarta

Erwiantono. 2004. Hubungan Antara Karakteristik Komunikasi dan Sikap Komunitas terhadap Perusahaan (Kasus Pertambangan Timah di Kabupaten Bangka Barat) Tesis. Institut Pertanian Bogor.

Fisher, R.J. 2001. Mengelola Konflik: Keterampilan dan Strategi untuk Bertindak. The British Council. Jakarta.

Fuad, F.H., \& Maskanah, S. 2000. Inovasi Penyelesaian Sengketa Pengelolaan Sumber Daya Hutan. Pustaka LATIN. Bogor

Greene, B.C. 1998. Environmental Water In Element of Practical Soil Mining 2. The American Institute of Mining Inc. New York.

Ismail, 2007. Analisis Implementasi Kebijakan Pertambangan Bahan Galian Golongan C di Kawasan Gunung Merapi Kabupaten Magelang. Tesis. Program Magister Ilmu Lingkungan Universitas Diponegoro.

Keraf, A.S. 2010. Etika Lingkungan Hidup. Kompas. Jakarta.

Mangkusubroto, K. 1995. Mining Investment Policy In Indonesia Current Issues and Future Outlook. Indonesia Mining Journal. 4 (1) : 60 - 62.

Mukarwoto, E.D. 1995. Developing Peat Mining In Indonesia and Ecological Sustainable Principles. Indonesia Mining Journal. $1: 87$ - 89.

Muslihudin., Bambang, A.N., Hendarto, E., dan Putranto, T.T. 2018. The impact of traditional gold mining in Gumelar Banyumas, Indonesia. Eco. Env. \& Cons. 24 (2) : 2018.

Naiola, B.P.T., Murtiningsih, \& Chairil. 1996. Pengaruh Stress Air terhadap Kualitas dan Kuantitas Komponen Aktif pada Sambiloto. Warta Tumbuhan Obat Indonesia. 3 : $15-17$.

Noor, D. 2006. Geologi Lingkungan. Graha Ilmu. Yogyakarta. Kementerian Lingkungan Hidup. 1996. Kepmen LH No. 43 Tahun 1996 tentang Kriteria Kerusakan Lingkungan bagi Usaha atau Kegiatan Penambangan Bahan Galian Golongan C Jenis Lepas di Dataran.

Kementerian Lingkungan Hidup. 1990. Peraturan Pemerintah No.20 Tahun 1990 tentang Pengendalian Pencemaran Air.

Kementerian Lingkungan Hidup dan Kehutanan. 2019. Peraturan Menteri Lingkungan Hidup No P 38 Tahun 2019 tentang Jenis Rencana Usaha dan/atau Kegiatan yang Wajib Memiliki Analisis Mengenai Dampak Lingkungan Hidup.

Kurbaniana E. 2012. Efektifitas arang tempurung kelapa dan bokashi pupuk kandang terhadap pertumbuhan bibit leda (Eucalyptus Deglupta Blume) di media tailing. Skripsi. Fakultas Kehutanan. Institut Pertanian Bogor. 
Pickering, P. 2000. How To Manage Conflict. National Press Publication. USA.

Pemerintah Kabupaten Kuningan. 2017. Rencana Pembangunan Jangka Menengah Daerah (RPJMD) Kabupaten Kuningan 2018 - 2023.

Ramadhan, M.F., Muslihudin., dan Effendi, M. 2021. Analisis Dampak Sosial Ekonomi Budaya Kegiatan Eksplorasi Panasbumi di WKP Baturraden (Studi Kasus di Desa Karangtengah, Kecamatan Cilongok, Kabupaten Banyumas). Jurnal Ilmu Lingkungan. 19(1), 117-126.

Salim, H.S. 2005. Hukum Pertambangan di Indonesia. PT. Raja Grafindo Persada. Jakarta.

Sinungan, M. 2003. Produktivitas Apa dan Bagaimana. Bumi Aksara. Jakarta.

Sitorus, S. 1985. Evaluasi Sumber Daya Lahan. Tarsito. Bandung.
Soemarwoto. O. 1985. Ekologi, Lingkungan Hidup dan Pembangunan. Penerbit Jambatan. Jakarta.

Suhartanto. 2007. Pedoman Teknis Reklamasi Lahan. Bahan Seminar Nasional Reklamasi Lahan. Jakarta.

Thoha M. 2004. Perilaku Organisasi: Konsep Dasar dan Aplikasinya. PT Raja Grafiindo. Jakarta.

Undang-Undang Nomor 4 Tahun 2009 tentang Pertambangan Mineral dan Batubara.

Wiryono, P. 2006. Pembangunan Pertanian Indonesia ke Depan : Ke Mana Mau Diarahkan. Kompas. Jakarta.

Young. 2004. Teknologi Pertambangan Indonesia. Pusat Penelitian dan Pengembangan Teknologi Mineral, Direktorat Jenderal Pertambangan Umum Departemen Pertambangan dan Energi. Jakarta.

Zulkifli, A. 2014. Pengelolaan Tambang Berkelanjutan. Graha Ilmu. Yogyakarta. 